\title{
A New Bamboo Rat from the Early Pleistocene of Renzidong Cave in Fanchang, Anhui, Central China
}

\author{
Guangbiao Wei*1, Yoshinari Kawamura*2 and Changzhu Jin*3
}

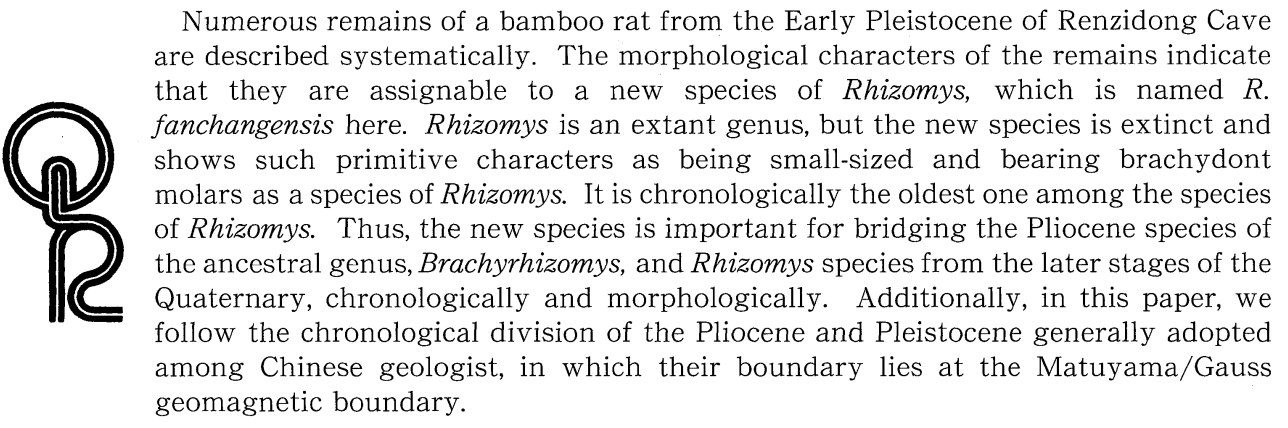

Keywords : Bamboo rat, New species, Early Pleistocene, Renzidong, Central China

\section{Introduction}

Bamboo rats, referred to the family Rhizomyidae, are a group of large muroid rodents which is adapted to fossorial life in various degrees and inhabits typically bamboo thickets. In present China, they live in rather restricted areas of the southern part including Sichuan Province. Their distribution is much wider during the Pliocene and Pleistocene, and a typical genus of them, Rhizomys, is one of the most representative elements in the Pleistocene mammal faunas of South China.

Very rich vertebrate remains were recently recovered from a limestone fissure-like cave called Renzidong which is situated in a quarry of Lailishan Hill, in Fanchang County, south- ern part of Anhui Province (Jin and Zheng, 1998, Fig. 1). The systematic excavations of the cave have revealed that the sediments yielding the remains can be dated as the earliest Pleistocene (2.0 to $2.4 \mathrm{Ma}$ ) of the Chinese chronological division (Jin et al., 2000), and produced abundant remains of a bamboo rat. The morphological study of the remains has convinced us of recognizing them as a new species of Rhizomys.

In this paper, we describe briefly the morphological characters of the remains, and give the reasons why we propose the new species. We intend to provide the results of the detailed morphological analyses and measurements including statistical data in a separate paper, because the data of the remains are nu-

Received August 1, 2003. Accepted October 11, 2003.

*1 Institute of Vertebrate Paleontology and Paleoanthropology, Chinese Academy of Sciences. P.O. Box 643, Beijing, China. (Present address: Department of Geosciences, Graduate School of Science, Osaka City University. 3-3-138 Sugimoto, Sumiyoshi-ku, Osaka, 558-8585, Japan.)

* 2 (Corresponding Author) Department of Earth Sciences, Aichi University of Education. 1 Hirosawa, Igaya-cho, Kariya, 448-8542, Japan. E-mail :

*3 Institute of Vertebrate Paleontology and Paleoanthropology, Chinese Academy of Sciences. P.O. Box 643, Beijing, China. 


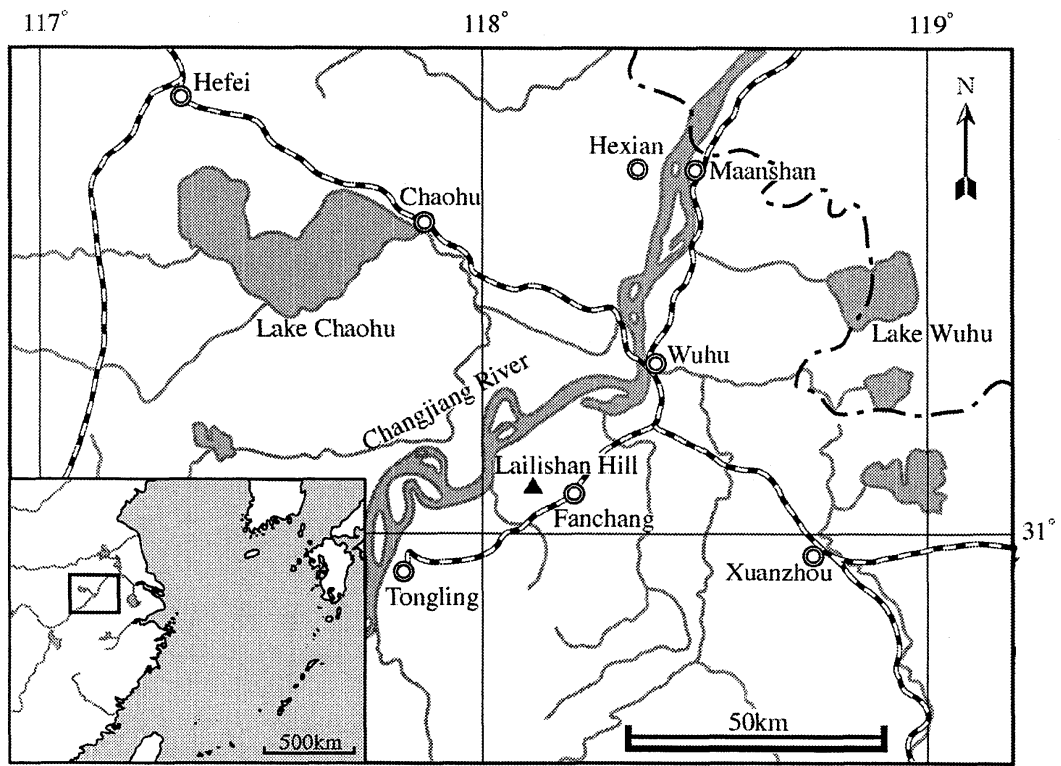

Fig. 1 Location map of Lailishan Hill

Renzidong Cave is situated in a limestone quarry on its southern slope.

merous and the description and explanation of the results need many pages. Additionally, in this paper, we follow the chronological division of the Pliocene and Pleistocene generally adopted among Chinese geologists, in which their boundary lies at the Matuyama/Gauss geomagnetic boundary (2.58 Ma) instead of the top of the Olduvai subchron (1.77 Ma).

\section{Geological setting}

Renzidong Cave is completely infilled by sediments which are divided into eight layers (Jin et al., 2000). According to Jin et al. (2000), these layers can be grouped into the upper part (1st to 7 th layers) with a thickness of about $15 \mathrm{~m}$, and the lower part (8th layer) with a thickness more than $15 \mathrm{~m}$. The former is composed of brown to reddish brown mud or sandy mud with limestone breccia and fallen blocks which contains abundant vertebrate remains including the remains of the bamboo rat described here. The latter is composed of gray sandy mud, sand and rounded gravel with few vertebrate remains.

Jin et al. (2000) identified 74 species of mammals in the vertebrate remains obtained from the upper part, and mentioned that the mam- mals contained both of the elements of North China and South China in nearly equal ratio. In comparison with the representative mammalian local faunas so far known from North and South China, they concluded that the age of the sediments was assigned to be the early stage of the Early Pleistocene ranging from 2.0 to $2.4 \mathrm{Ma}$.

\section{Terminology and measuring method}

The molars described here fundamentally bear lophodont patterns in their crowns, and comprise several transverse or oblique laminae. The terminology of the molars used here is shown in Figure 2, which basically follows those of rhizomyid molars by Jacobs (1978) and Flynn (1982). In the molars except $\mathrm{M}^{1}$ and $\mathrm{M}_{1}$, we use the term "lamina" instead of formal terminology, when the homology of the laminae is uncertain among the molars, $\mathrm{M}^{1}$ and $\mathrm{M}_{1}$. Additional descriptive terms for the skull, mandible and molars are shown in Figure 3.

The measuring method is also shown in Figure 3. As regards skull measurements, the length of the upper diastema (1) is measured from the posterior end of the alveolus of the 

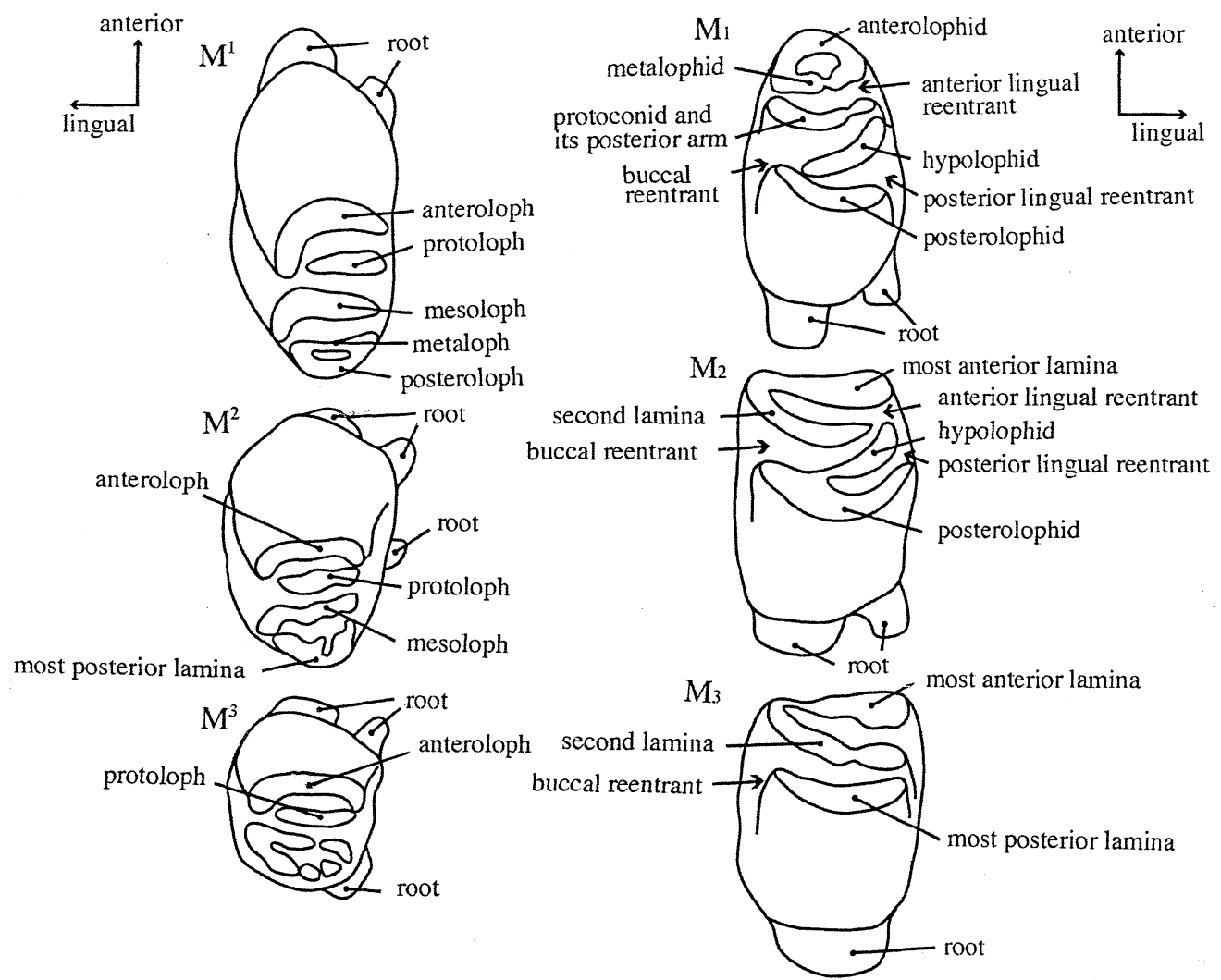

Fig. 2 Terminology of the molars
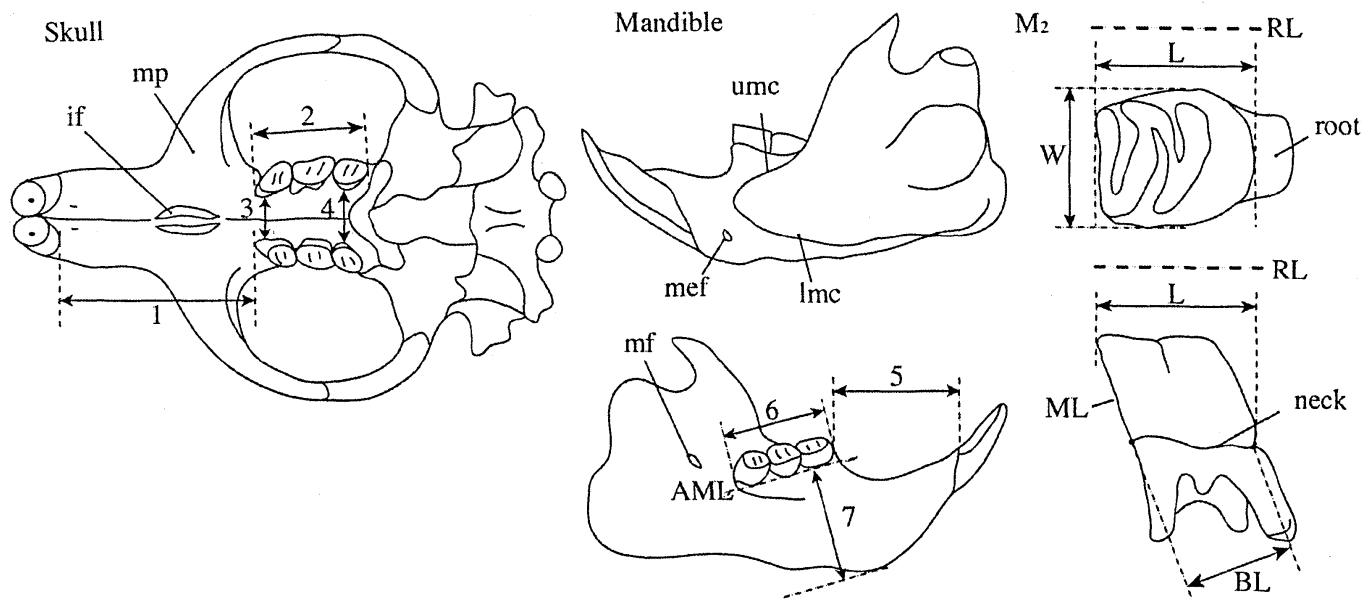

Fig. 3 Measuring method of the skull, mandible and molars

1. length of the upper diastema, 2. length of the upper molar row, 3. width of the palate at $\mathrm{M}^{1}$, 4. width of the palate at $\mathrm{M}^{3}$, 5. length of the lower diastema, 6. length of the lower molar row, 7. maximum height of the mandible. AML : alveolar marginal line, BL : basal length of the crown, if : incisive foramen, $\mathrm{L}:$ length of the crown, lmc : lower masseteric crest, mef : mental foramen, $\mathrm{mf}$ : mandibular foramen, ML: marginal line of the crown, $\mathrm{mp}$ : masseteric plate, RL : reference line, umc : upper masseteric crest, $\mathrm{W}$ : width of the crown. 
upper incisor to the anterior end of the alveolus of $\mathrm{M}^{1}$ along the midline of the skull. The length of the upper molar row (2) is the distance from the anterior end of the alveolus of $\mathrm{M}^{1}$ to the posterior end of the alveolus of $\mathrm{M}^{3}$. The widths of the palate at $\mathrm{M}^{1}$ and $\mathrm{M}^{3}$ ( 3 and 4 ) are measured between the most lingual points of the alveoli of $\mathrm{M}^{1}$ and $\mathrm{M}^{3}$ respectively.

As regards the mandibles, the length of the lower diastema (5) is the distance from the anterior end of the mandible to that of the alveolus of $M_{1}$. The length of the lower molar row (6) is measured from the anterior end of the alveolus of $\mathrm{M}_{1}$ to the posterior end of the alveolus of $\mathrm{M}_{3}$. The maximum height of the mandible (7) is the distance between the alveolar margin of $M_{1}$ and the lowest point of the mandible measured perpendicular to the alveolar marginal line (AML).

As regards the molars, the measurements of the length (L) and width (W) basically follow those of Flynn (1982). L and W are measured parallel and perpendicular to the long axis of the crown as a reference line (RL) in occlusal view, respectively. In side views, this line is parallel to the occlusal surface of the crown. Additionally, in order to compare the data of Zheng (1993), we measure the basal length of the crown (BL) perpendicular to the posterior marginal line in the upper molars and the anterior marginal line in the lower molars (ML).

All the measurements are taken to the nearest $0.001 \mathrm{~mm}$ using a measure scope (Nikon MM-11) with an electric digital counter (Nikon CM-65). The measured data are rounded up to $0.01 \mathrm{~mm}$ and recorded in Tables 1 to 3 .

\section{Systematic description}

Family Rhizomyidae Miller and Gidley, 1918

Subfamily Rhizomyinae Winge, 1887

Genus Rhizomys Gray, 1831

Rhizomys fanchangensis, sp. nov.

(Figs. 4-8)

Holotype-Left mandible with $\mathrm{I}, \mathrm{M}_{1}, \mathrm{M}_{2}$ and $\mathrm{M}_{3}$ (V13894.011).

Paratype-Fragmentary skull with left and right complete tooth series (V13894.001)

Hypodigm - 2 fragmentary skulls with left and right $\mathrm{I}, \mathrm{M}^{1}-\mathrm{M}^{3}$ (V13894.002 and $\mathrm{V}$ 13894.003), 1 fragmentary skull with left I, $M^{1}$ -
$\mathrm{M}^{3}$ and right $\mathrm{I}, \mathrm{M}^{2}, \mathrm{M}^{3}$ (V13894.004), 1 fragmentary skull with left $\mathrm{I}, \mathrm{M}^{1}, \mathrm{M}^{2}$ and right $\mathrm{I}$, $\mathrm{M}^{1}-\mathrm{M}^{3}$ (V13894.005), 2 skull fragments with left $\mathrm{M}^{1}-\mathrm{M}^{3}$ and right $\mathrm{M}^{2}, \mathrm{M}^{3}$ (V13894.006 and $\mathrm{V}$ 13894.007), 1 left and right premaxillary fragment with left and right I (V13894.008), 1 left fragmentary maxilla with $\mathrm{M}^{2}$ and $\mathrm{M}^{3}$ (V 13894.009), 1 right fragmentary maxilla with $\mathrm{M}^{2}$ (V13894.010), 8 left mandibles with $\mathrm{I}, \mathrm{M}_{1}-\mathrm{M}_{3}$ (V13894.012-V13894.019), 3 right mandibles with I, $\mathrm{M}_{1}-\mathrm{M}_{3}$ (V13894.033-V13894.035), 2 left mandibles with $\mathrm{I}, \mathrm{M}_{1}, \mathrm{M}_{2}$ (V13894.020 and V 13894.021), 2 right mandibles with $\mathrm{I}_{1} \mathrm{M}_{1}, \mathrm{M}_{2}$ (V 13894.036 and V13894.037), 3 left mandibles with I, $\mathrm{M}_{2}, \mathrm{M}_{3}$ (V13894.022-V13894.024), 1 right mandible with $\mathrm{I}, \mathrm{M}_{2}, \mathrm{M}_{3}$ (V13894.038), 2 left fragmentary mandibles with $\mathrm{M}_{1}-\mathrm{M}_{3}$ (V 13894.025 and V13894.026), 2 right fragmentary mandibles with $\mathrm{M}_{1}-\mathrm{M}_{3}$ (V13894.039 and $\mathrm{V}$ 13894.040), 1 left mandible with $\mathrm{I}$ and $\mathrm{M}_{3}$ (V 13894.027), 1 right fragmentary mandible with I, $\mathrm{M}_{2}, \mathrm{M}_{3}$ (V13894.041), 1 right fragmentary mandible with $\mathrm{M}_{1}$ and $\mathrm{M}_{2}$ (V13894.042), 1 left mandible with $\mathrm{M}_{2}, \mathrm{M}_{3}$ (V13894.028), 2 right fragmentary mandibles with $\mathrm{M}_{2}$ and $\mathrm{M}_{3}(\mathrm{~V}$ 13894.043 and V13894.044), 3 left mandibular fragments with $\mathrm{M}_{2}$ and $\mathrm{M}_{3}$ (V13894.029-V 13894.031), 1 right mandible with $\mathrm{I}$ and $\mathrm{M}_{2}(\mathrm{~V}$ 13894.045), 1 right fragmentary mandible with I and $\mathrm{M}_{2}$ (V13894.046), 1 left mandibular fragment with $\mathrm{I}$ and $\mathrm{M}_{2}$ (V13894.032), 2 right mandibular fragments without teeth (V 13894.047 and V13894.048), 5 left isolated $\mathrm{M}^{1}(\mathrm{~V}$ 13894.049-V13894.053), 4 right isolated $\mathrm{M}^{1}(\mathrm{~V}$ 13894.054-V13894.057), 28 left isolated $\mathrm{M}^{2}$ (V 13894.058-V13894.085), 27 right isolated $\mathrm{M}^{2}(\mathrm{~V}$ 13894.087-V13894.113), 21 left isolated $\mathrm{M}^{3}$ (V 13894.114-V13894.134), 28 right isolated $\mathrm{M}^{3}$ (V 13894.135-V13894.162), 25 left isolated $M_{1}$ (V 13894.163-V13894.187), 24 right isolated $\mathrm{M}_{1}(\mathrm{~V}$ 13894.188-V13894.211), 29 left isolated $\mathrm{M}_{2}$ (V 13894.212-V13894.240), 25 right isolated $\mathrm{M}_{2}(\mathrm{~V}$ 13894.241-V13894.265), 22 left isolated $\mathrm{M}_{3}$ (V 13894.266-V13894.287), 22 right isolated $\mathrm{M}_{3}(\mathrm{~V}$ 13894.288-V13894.309).

Repository-All the specimens are stored in Institute of Vertebrate Paleontology and Paleoanthropology, Chinese Academy of Sciences, Beijing.

Name derivation-Fanchang is the name of 
the county where the fossil locality is situated.

Locality and horizon-2nd to 7th layers of Renzidong Cave (Renzi Cave) in a limestone quarry on the southern slope of Lailishan Hill (Laili Hill), Suncun, Fanchang County, Anhui Province, central China $\left(118^{\circ} 5^{\prime} 46^{\prime \prime} \mathrm{E}, 31^{\circ} 5^{\prime} 23^{\prime \prime} \mathrm{N}\right)$

Geological age-Early Pleistocene (probably $2.0-2.4 \mathrm{Ma})$

\section{Diagnosis}

A small species of Rhizomys with primitive dental characters as a member of the genus; size nearly as large as that of $R$. brachyrhizomysoides, but decidedly smaller than other species of Rhizomys; molars with lophodont pattern typical to species of Rhizomys, but lower-crowned than those of the Rhizomys species so far known including $R$. brachyrhizomysoides; longitudinal groove on the lingual face of the upper molars extending more dorsally, and buccal reentrant on the buccal face of the lower molars extending more ventrally than in the Rhizomys species so far known.

\section{Description}

Skull : All the skulls are considerably damaged, and most of them are strongly deformed by lateral pressure. Their brain cases are lost, and the nasals, incisive foramina and infraorbital foramina cannot be observed owing to poor preservation of the specimens. In lateral view, the rostrum with a wide masseteric plate is morphologically similar to that of extant species of Rhizomys. Its ventral margin gently curves dorsally in lateral view. The length of the diastema exceeds that of the upper molar row (Table 1). The bony palate is narrow, and the molar row is short in relation to the skull size. In ventral view, the molar row shows a gentle curve slightly expanded buccally in its central or posterior part, so that the width of the palate between the left and right molar rows attains its maximum at $\mathrm{M}^{2}$ or at $\mathrm{M}^{3}$.

Upper incisor : The apical part of the incisor extends almost vertically from the premaxilla,

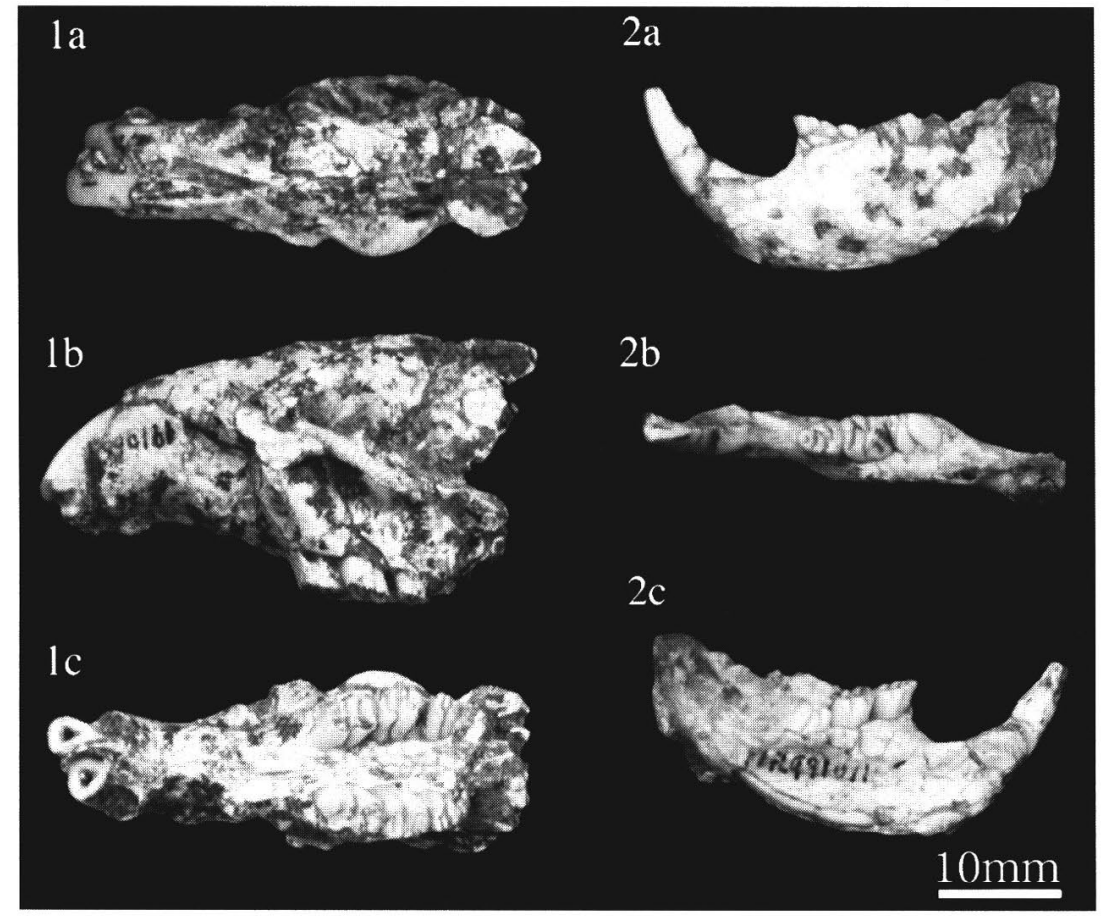

Fig. 4 Rhizomys fanchangensis, sp. nov. from the Early Pleistocene of Renzidong Cave $1 \mathrm{a}-1 \mathrm{c}$. skull with left $\mathrm{I}, \mathrm{M}^{1}, \mathrm{M}^{2}$ and $\mathrm{M}^{3}$, and with right $\mathrm{I}, \mathrm{M}^{1}, \mathrm{M}^{2}$ and $\mathrm{M}^{3}$ (paratype: V13894.001, la. dorsal view, 1b. left lateral view, 1c. palatal view). 2a 2c. left mandible with $\mathrm{I}, \mathrm{M}_{1}, \mathrm{M}_{2}$ and $\mathrm{M}_{3}$ (holotype: V13894.011, 2a. buccal view, 2b. dorsal view, 2c. lingual view). 
and its posterior end reaches above $\mathrm{M}^{1}$. The cross section of the incisor is roundly triangular (Fig. 5). The enamel is relatively thin and covers about one-fourth of the lingual and buccal faces. The surface of the enamel is smooth and has neither longitudinal grooves nor ridges. The enamel of the anterior part of the incisor is pigmented orange to yellow, but that of the other part is white in color.

Upper molars (common features) : The upper molars are relatively high-crowned, but the hypsodonty is less developed than in the species of Rhizomys so far known. The basal parts of their crowns curve lingually, so that the crown heights measured on their lingual faces are much larger than those on their buccal faces. A deep transverse groove crosses the central part of the occlusal surface of each molar, and is observable on both of the lingual and buccal faces of the crown, except in strongly worn specimens. The groove observed on the lingual face is much longer than that observed on the buccal face. The groove terminates at the position considerably ventral to the neck, but the position is nearer to the neck than in the other species of Rhizomys.

$\mathbf{M}^{1}$ : The crown is basically formed by four transverse laminae which are tilted anteriorly. In occlusal view, the crown has an oval outline. The most anterior lamina, anteroloph, shapes an asymmetrical arc in occlusal view. Its anterior face is smooth and shows no trace of the anterolingual flexus. The second lamina, protoloph, runs almost straight transversely. It is much shorter than the third lamina, mesoloph, which is slightly arcuate. It extends almost parallel to the protoloph. The most posterior lamina is formed by the coalescence of the metaloph and posteroloph. This can be observed in slightly or moderately worn specimens. $\mathrm{M}^{1}$ has four roots.

$\mathbf{M}^{2}$ : As in $\mathrm{M}^{1}$, the crown is formed by four transverse laminae which are tilted anteriorly. In occlusal view, the crown has an oval or rounded rectangular outline which is more shortened anteroposteriorly than that of $\mathrm{M}^{1}$. The anteroloph runs almost straight transversely, or is somewhat arcuate. The protoloph and mesoloph runs almost parallel to the anteroloph. The most posterior lamina varies from

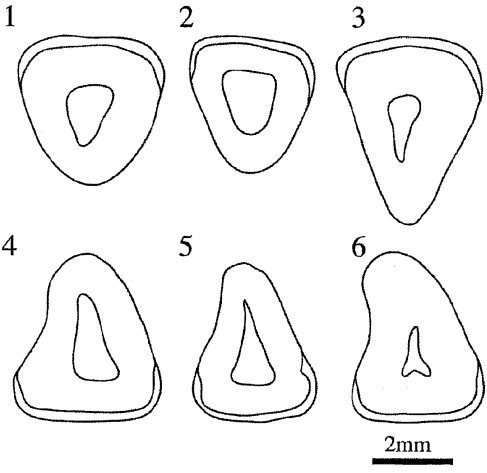

Fig. 5 Rhizomys fanchangensis, sp. nov. The cross sections of the left upper incisors $(1-3)$ and the left lower incisors (4-6). 1. V13894.002, 2. V 13894.001 (paratype), 3. V 13894.003, 4. V 13894.018, 5. V13894.019, 6. V13894.024.

a slightly arcuate slender lamina-shape to an anteroposteriorly broad crescent. $\mathrm{M}^{2}$ also has four roots.

$\mathbf{M}^{3}$ : The crown is much smaller than those of $\mathrm{M}^{1}$ and $\mathrm{M}^{2}$. It is remarkably shortened anteroposteriorly, so that it shows a round outline, or a triangular outline with round corners in occlusal view. The crown is basically formed by three or four transverse laminae. Among the laminae, the most anterior one, anteroloph, is clearly tilted anteriorly, while the most posterior one is almost vertical. The laminae between them are slightly tilted anteriorly. In occlusal view, the anteroloph is straight transversely or somewhat arcuate. The protoloph is much shorter than the anteroloph. The crown pattern posterior to the protoloph is quite variable. In some specimens, there is only one arcuate lamina, but in other specimens, there are two laminae. These laminae may be divided into several cusplets in slightly or weakly worn specimens. $\mathrm{M}^{3}$ bears three roots.

Mandible : The diastema is shorter than the lower molar row (Table 2). The upper and lower masseteric crests are generally well defined on the buccal face of the horizontal ramus, and intersect below the anterior margin of $\mathrm{M}_{1}$. This intersection is higher than the middle point of the total height of the mandible below $M_{1}$. The mental foramen is situated anteroventrally to the intersection and slightly lower than the middle point. From the inter- 
section, the upper masseteric crest extends posterodorsally to be continuous to the anterior margin of the coronoid process, and the lower masseteric crest runs posteroventrally toward the lower margin of the mandibular angle. The lower masseteric crest never extends anteriorly beyond the intersection. The lingual face of the horizontal ramus is smooth and slightly concave longitudinally. The mandibular foramen opens considerably posterior to $\mathrm{M}_{3}$ and at the same level as the occlusal surface of the lower molars. The area between the ascending ramus and molar row is perforated by small nutritive foramina. The lower incisor passes below $\mathrm{M}_{3}$ from the lingual side to the buccal side of the mandible, and extends posterodorsally and also buccally, high above the occlusal level of the molars.

Lower incisor : Its anterior tip is generally higher than or nearly as high as the occlusal level of the lower molars, when the incisor is planted in the mandible. In cross section, it shapes a triangle with round corners (Fig. 5). The lingual margin of the triangle is slightly concave, while its buccal and ventral margins are slightly convex and almost straight respectively. As in the upper incisor, the enamel is relatively thin, and covers about one-fourth of the lingual and buccal faces of the incisor. It has a smooth surface without any longitudinal ridge or groove, and is pigmented orange to yellow anteriorly but is white posteriorly.

Lower molars (common features): The lower molars are relatively high-crowned, as in the upper molars, but the hypsodonty is not so developed as in the other species of the genus Rhizomys so far known. The crown does not curve lingually or buccally. Except in strongly worn specimens, one or two longitudinal grooves are observed on the buccal face of each molar, and two are observed on its lingual face. These grooves terminate high above the neck, but their ventral ends are nearer to the neck than in the other species of Rhizomys. The mesolophid cannot be distinguished from the protoconid and its posterior arm.

$\mathbf{M}_{1}$ : The crown is basically formed by five crescentic laminae extending transversely or obliquely, which are tilted posteriorly. In occlusal view, the crown has an oval outline
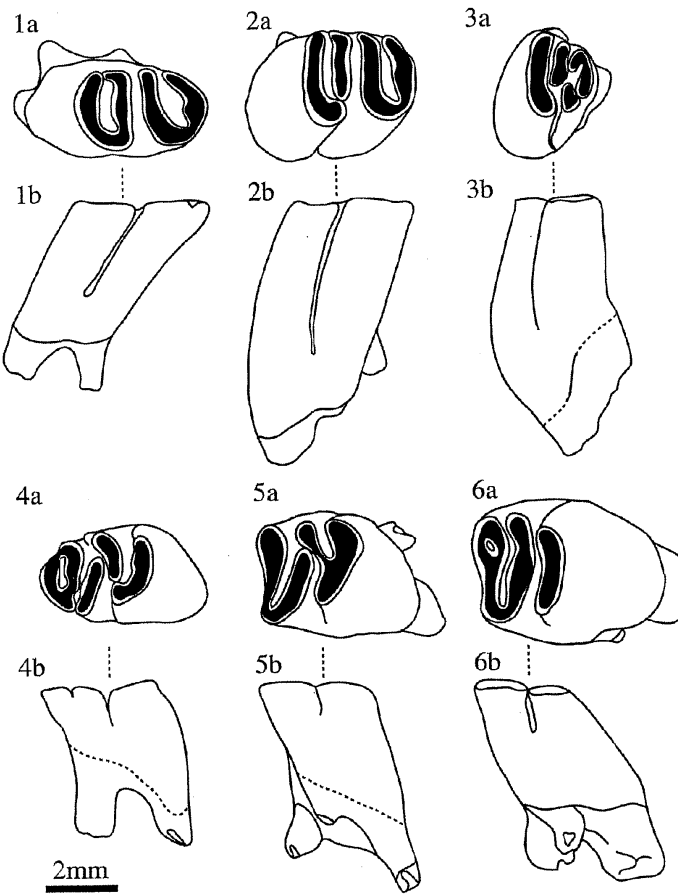

Fig. 6 Molars of Rhizomys fanchangensis, sp. nov. 1a, 1b. left $\mathrm{M}^{1}$ (V13894.049), 2a, 2b. left $\mathrm{M}^{2}$ (V 13894.062), 3a, 3b. left $\mathrm{M}^{3}$ (V13894.118), 4a, 4b. left $\mathrm{M}_{1}$ (V13894.169), 5a, 5b. left $\mathrm{M}_{2}$ (V13894.215), 6a, 6b. left $\mathrm{M}_{3}$ (V13894.268). 1a, 2a, 3a, 4a, 5a, 6a. occlusal view, 1b, 2b, 3b. lingual view, 4b, 5b, 6 b. buccal view

considerably elongated anteroposteriorly. The most anterior lamina, anterolophid, shows an arcuate shape convexing anteriorly. The second lamina, metalophid, runs straight transversely or shows an arcuate shape convexing posteriorly. These two laminae connect to each other at both of their lingual and buccal ends, and form an enamel lake inside. The third lamina, probably protoconid and its posterior arm, shows a crescentic shape convexing posteriorly. It extends somewhat obliquely to the transverse axis of the crown, or extends almost transversely. The mure connecting this lamina to the fourth lamina in the central part of the crown is mostly absent, but appears in few moderately or strongly worn specimens. The fourth lamina, hypolophid, has a crescentic shape convexing posteriorly, and extends obliquely. The most posterior lamina, pos- 
terolophid, also has a crescentic shape convexing posteriorly. It extends transversely or somewhat obliquely. In side views, the buccal reentrant, which is somewhat deeper than the posterior lingual reentrant, somewhat exceeds the anterior lingual reentrant in depth. $\mathrm{M}_{1}$ has three roots.

$\mathbf{M}_{2}$ : The crown is formed by four transverse or oblique laminae which are tilted posteriorly. In occlusal view, it has a roundly rectangular outline with an almost straight anterior margin. The most anterior lamina extends transversely and broadens lingually. The second lamina is narrowly crescentic and extends obliquely to the transverse axis of the crown. Its buccal end is continuous to that of the most anterior lamina even in slightly worn specimens. The mure is absent between the buccal parts of the second and third laminae. The third lamina, hypolophid, is also crescentic, but is shorter than the second lamina. The hypolophid extends obliquely, but is set in an alternating position with the second lamina. In moderately worn specimens, the hypolophid connects to the central part of the most posterior lamina, posterolophid. The posterolophid is crescentic, and basically extends transversely. In side views, the anterior lingual and posterior lingual reentrants have nearly the same depth, while the buccal reentrant is much deeper than the two reentrants. $\mathrm{M}_{2}$ bears four roots.

$\mathbf{M}_{3}$ : The crown structure is basically the same as that of $\mathrm{M}_{2}$, but the lamina corresponding to the hypolophid of $\mathrm{M}_{2}$ is not recognizable. Thus the crown comprises three transverse or oblique laminae, which are tilted posteriorly. In occlusal view, it has a roundly rectangular outline as that of $\mathrm{M}_{2}$, and its anterior margin is also almost straight. The most anterior lamina is morphologically the same as that of $\mathrm{M}_{2}$. The second lamina is narrowly crescentic and extends obliquely. The mure is absent as in $\mathrm{M}_{2}$. The most posterior lamina basically extends transversely and shows a narrowly crescentic or elliptical shape in occlusal view. $\mathrm{M}_{3}$ has three roots.

\section{Measurements}

The measurements of the skulls, mandibles and molars are given in Tables 1,2 and 3 re- spectively.

\section{Comparison and Discussion}

The morphology of the specimens described above well agrees with that of the family Rhizomyidae. Namely the specimens have myomorphous zygoma in skulls; their palates are narrow ; mandibles have strong lower and upper masseteric crests which meet high on the buccal face; molars are three in number both on one side of the maxillae and on that of the mandibles; molars are hypsodont and lophodont with the patterns typical to the rhizomyids; the occlusal surfaces are tilted buccally in the upper molars but lingually in the lower molars. Thus the specimens are undoubtedly assigned to the family, which comprises two subfamilies, Tachyoryctinae and Rhizomyinae (Flynn, 1982).

On the basis of the reappraisal of the Miocene and Pliocene rhizomyids from the Siwalik sediments of Pakistan and India, Flynn (1982) gave emended diagnoses of the subfamilies. His diagnoses indicate that the specimens described here are easily distinguishable from Tachyoryctinae in having the mandible with no anterior extension of the lower masseteric crest, the molars relatively smaller, $\mathrm{M}^{1}$ without the anterolingual flexus, the lower incisor without a longitudinal ridge on the enamel, and $\mathrm{M}_{3}$ without a large enamel lake posterolingual to the buccal reentrant. On the other hand, his diagnoses of Rhizomyinae well agree with the morphological characters of the present specimens. Thus, the specimens are referred to the subfamily. Flynn (1982) included the following four genera in Rhizomyinae :

Brachyrhizomys Teilhard de Chardin, 1942

Anepsirhizomys Flynn, 1982

Cannomys Thomas, 1915

Rhizomys Gray, 1931

Besides these, Teilhard de Chardin and Young (1931) proposed the genus Pararhizomys from the Pliocene of Shaanxi Province. Pararhizomys has a very simple molar pattern which is dissimilar to other rhizomyids and the present specimens. Thus, we exclude Pararhizomys from the present comparison.

Among the more reliable genera listed above, Brachyrhizomys was first described from the Pliocene of northern China by Teilhard de 
Table 1 Measurements of the skulls of Rhizomys fanchangensis, sp. nov. in mm

\begin{tabular}{lcccc}
\hline & $\begin{array}{c}\text { V13894.001 } \\
\text { (paratype) }\end{array}$ & V13894.003 & V13894.004 & V13894.006 \\
\hline Length of the upper diastema & 14.84 & 18.29 & 15.40 & - \\
Length of the upper molar row & 11.91 & 11.91 & 12.94 & 11.55 \\
Width of the palate at $\mathrm{M}^{1}$ & 2.69 & 2.73 & - & - \\
Width of the palate at $\mathrm{M}^{3}$ & 3.44 & 4.66 & - & 3.52 \\
\hline
\end{tabular}

Table 2 Measurements of the mandibles of Rhizomys fanchangensis, sp. nov. in $\mathrm{mm}$

\begin{tabular}{|c|c|c|c|c|c|c|c|}
\hline & $\begin{array}{c}\text { V13894. } \\
011 \\
\text { (holotype) }\end{array}$ & $\begin{array}{c}\text { V13894. } \\
012\end{array}$ & $\begin{array}{c}\text { V13894. } \\
015\end{array}$ & $\begin{array}{c}\text { V13894. } \\
019\end{array}$ & $\begin{array}{c}\text { V13894. } \\
023\end{array}$ & $\begin{array}{c}\text { V13894. } \\
027\end{array}$ & $\begin{array}{c}\text { V13894. } \\
044\end{array}$ \\
\hline $\begin{array}{l}\text { Length of the } \\
\text { lower diastema }\end{array}$ & 9.47 & - & 10.98 & - & - & - & - \\
\hline $\begin{array}{l}\text { Length of the } \\
\text { lower molar row }\end{array}$ & 11.33 & - & - & 11.01 & 12.18 & 12.05 & 11.55 \\
\hline $\begin{array}{l}\text { Maximum height } \\
\text { of the mandible }\end{array}$ & 9.83 & 10.72 & - & - & 10.92 & 12.82 & 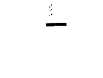 \\
\hline
\end{tabular}

Table 3 Measurements of the molars of Rhizomys fanchangensis, sp. nov. in mm

\begin{tabular}{|c|c|c|c|c|c|c|c|}
\hline & $\mathrm{L}$ & $\mathrm{W}$ & $\mathrm{BL}$ & & $\mathrm{L}$ & W & $\mathrm{BL}$ \\
\hline \multicolumn{8}{|l|}{$\mathbf{M}^{1}$} \\
\hline $\begin{array}{c}\text { V13894.001 } \\
\text { (paratype) }\end{array}$ & 4.96 & 3.61 & - & $\begin{array}{c}\text { V13894.011 } \\
\text { (holotype) }\end{array}$ & 3.72 & 2.96 & - \\
\hline V13894.049 & 5.61 & 3.13 & 2.79 & V13894.163 & 5.10 & 2.99 & 3.15 \\
\hline V13894.052 & 5.85 & 3.36 & 2.85 & V13894.169 & 4.44 & 3.15 & 2.72 \\
\hline \multicolumn{4}{|l|}{$\mathrm{M}^{2}$} & \multicolumn{4}{|l|}{$\mathrm{M}_{2}$} \\
\hline $\begin{array}{c}\text { V13894.001 } \\
\text { (paratype) }\end{array}$ & 4.06 & 3.77 & - & $\begin{array}{c}\text { V13894.011 } \\
\text { (holotype) }\end{array}$ & 4.22 & 3.89 & - \\
\hline V13894.060 & 5.52 & 4.11 & 2.79 & V13894.215 & 4.92 & 4.14 & 2.38 \\
\hline V13894.062 & 5.19 & 3.95 & 2.45 & V13894.246 & 4.44 & 3.92 & 3.20 \\
\hline \multicolumn{4}{|l|}{$\mathrm{M}^{3}$} & \multicolumn{4}{|l|}{$\mathrm{M}_{3}$} \\
\hline $\begin{array}{c}\text { V13894.001 } \\
\text { (paratype) }\end{array}$ & - & 3.54 & - & $\begin{array}{c}\text { V13894.011 } \\
\text { (holotype) }\end{array}$ & - & 3.50 & - \\
\hline V13894.118 & 3.04 & 3.86 & 3.05 & V13894.268 & 6.13 & 4.53 & 3.48 \\
\hline \multirow[t]{2}{*}{ V13894.151 } & 3.95 & 4.19 & 2.90 & V13894.289 & 5.59 & 4.52 & 3.26 \\
\hline & & & & V13894.298 & 5.14 & 4.22 & 2.50 \\
\hline
\end{tabular}

Chardin (1942), and then Flynn (1982) referred many rhizomyines known from the Late Miocene sediments in the Siwaliks to this genus. Flynn (1982) provided the emended diagnosis of this genus, although Flynn (1993) treated Brachyrhizomys as a subgenus of Rhizomys. Among the characters given by Teilhard de Chardin (1942) and Flynn (1982, 1993), the followings distinguish Brachyrhizomys from the present specimens. Brachyrhizomys has lowercrowned molars, a longer diastema of the mandible and more elongated $\mathrm{M}_{3}$ (Fig. 7). The mure and mesolophid are recognizable in $\mathrm{M}_{2}$ and mostly in $\mathrm{M}_{3}$ of Brachyrhizomys, but they are absent or indistinguishable in $\mathrm{M}_{2}$ and $\mathrm{M}_{3}$ of the present specimens. An enamel lake is easily formed posterolingual to the buccal reentrant in $\mathrm{M}_{2}$ of Brachyrhizomys, but the posterior lin- 
gual reentrant persists even in strongly worn $\mathrm{M}_{2}$ of the present specimens. $\mathrm{M}_{1}, \mathrm{M}_{2}$ and $\mathrm{M}_{3}$ of Brachyrhizomys bear two, three and two roots respectively, instead of three, four and three roots in the case of the present specimens. The lower margin of the mandible is sub-concave in Brachyrhizomys, but it is somewhat convex in the present specimens. The lower incisor leans anteriorly and its anterior tip does not reach the occlusal level of the lower molars in Brachyrhizomys (see Fig. 23 of Teilhard de Chardin, 1942), while it extends more upward and its anterior tip is somewhat higher in the present specimens.

Anepsirhizomys was established by only one mandible from the Pliocene sediments in the Siwaliks by Flynn (1982). On the basis of his description and figure, Anepsirhizomys differs from the present specimens in having the following characters: $\mathrm{M}_{1}$ of Anepsirhizomys shows the central mure even in an early stage of wear, which distinguishes the mesolophid from the posterior arm of protoconid. In $\mathrm{M}_{1}$ of the present specimens, however, the mure is never seen in the same stage of wear, although it appears in few moderately or strongly worn specimens. In $\mathrm{M}_{1}$ of Anepsirhizomys, the posterolophid joins the hypolophid lingually to form an enamel lake, while these laminae are well separated lingually in $\mathrm{M}_{1}$ of the present specimens. In $\mathrm{M}_{2}$ of Anepsirhizomys, the hypolophid extends transversely and joins the posterolophid at its buccal end, while it extends obliquely and joins the posterolophid more lingually (mostly at its central part) in $\mathrm{M}_{2}$ of the present specimens.

Cannomys is an extant genus of the rhizomyines. Corbet and Hill (1992) and Huang et al. (1995) provide diagnostic characters of the genus. Of the characters, those of the upper incisor and molars distinguish Cannomys from the present specimens. The upper incisor projects forward from the premaxilla in Cannomys, while it is almost vertical in the present specimens. As regards the upper molars, $\mathrm{M}^{1}$ is larger than $\mathrm{M}^{2}$ in Cannomys, while $\mathrm{M}^{1}$ is smaller than or nearly the same size as $\mathrm{M}^{2}$ in the present specimens.

Among the rhizomyines listed above, the remaining genus, Rhizomys, bears common characters in skull, mandibular and dental morphology to the present specimens. Namely, the upper incisor extends almost vertically from the skull ; the lower margin of the mandible is somewhat convex ventrally; the diastema of the mandible is shorter ; the lower incisor is not proclive; the molars are remarkably hypsodont in various degree and show basically the same pattern. In $\mathrm{M}_{2}$ and $\mathrm{M}_{3}$, the mure is absent, so that the mesolophid is not distinguishable from the posterior arm of protoconid; the crown of $\mathrm{M}_{3}$ is relatively shortened anteroposteriorly; the roots of the lower molars are more in number than those of Brachyrhizomys. Thus the present specimens are referred to the genus Rhizomys, which includes the following six species:

Rhizomys schlosseri Young, 1927

$R$. brachyrhizomysoides Zheng, 1991

R. troglodytes Matthew and Granger, 1923

$R$. sinensis Gray, 1831

$R$. sumatrensis Raffles 1821

$R$. pruinosus Blyth, 1851

Among the species, $R$. schlosseri was described from the Pleistocene loess of Henan Province on the basis of only one skull by Young (1927). The validity of $R$. schlosseri is questionable, because of the similarity of its
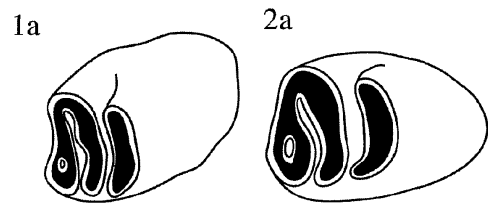

$1 \mathrm{~b}$

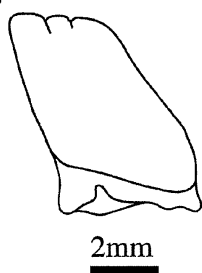

$2 \mathrm{~b}$

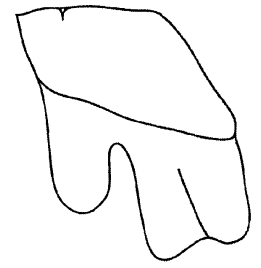

Fig. $7 \mathrm{M}_{3}$ of Rhizomys fanchangensis, sp. nov. (1a, 1b) and Brachyrhizomys shansius (2a, 2b)

Comparison of hypsodonty in $\mathrm{M}_{3}$ of the same stage of wear. 1a, 2a. occlusal view, 1b, $2 \mathrm{~b}$. lingual view. 1a, 1b. V13894.289, 2a, 2b. drawn from the cast of 31.096 , which is also illustrated in Figs. 22 and 24 of Teilhard de Chardin (1942) 
skull to those of extant species of Rhizomys. At any rate, $R$. schlosseri is easily distinguishable from the present specimens in its strikingly larger size.

$R$. brachyrhizomysoides was first proposed as an extinct species by relatively few isolated molars from Early Pleistocene cave sediments of Longgupo, Sichuan, in Ye et al. (1991). Subsequently, Zheng (1993) described them in detail with additional isolated molars. Judging from the descriptions and figures of these papers, $R$. brachyrhizomysoides is similar to the present specimens in having small size and relatively brachydont molars, but clearly differs from the specimens in the following features: in side views, the longitudinal grooves of the upper molars and the reentrants of the lower molars terminate more remotely apart from the neck in $R$. brachyrhizomysoides (Fig. 8). This suggests that the molars of this species are more hypsodont than those of the present specimens. Zheng (1993) mentioned that the molars

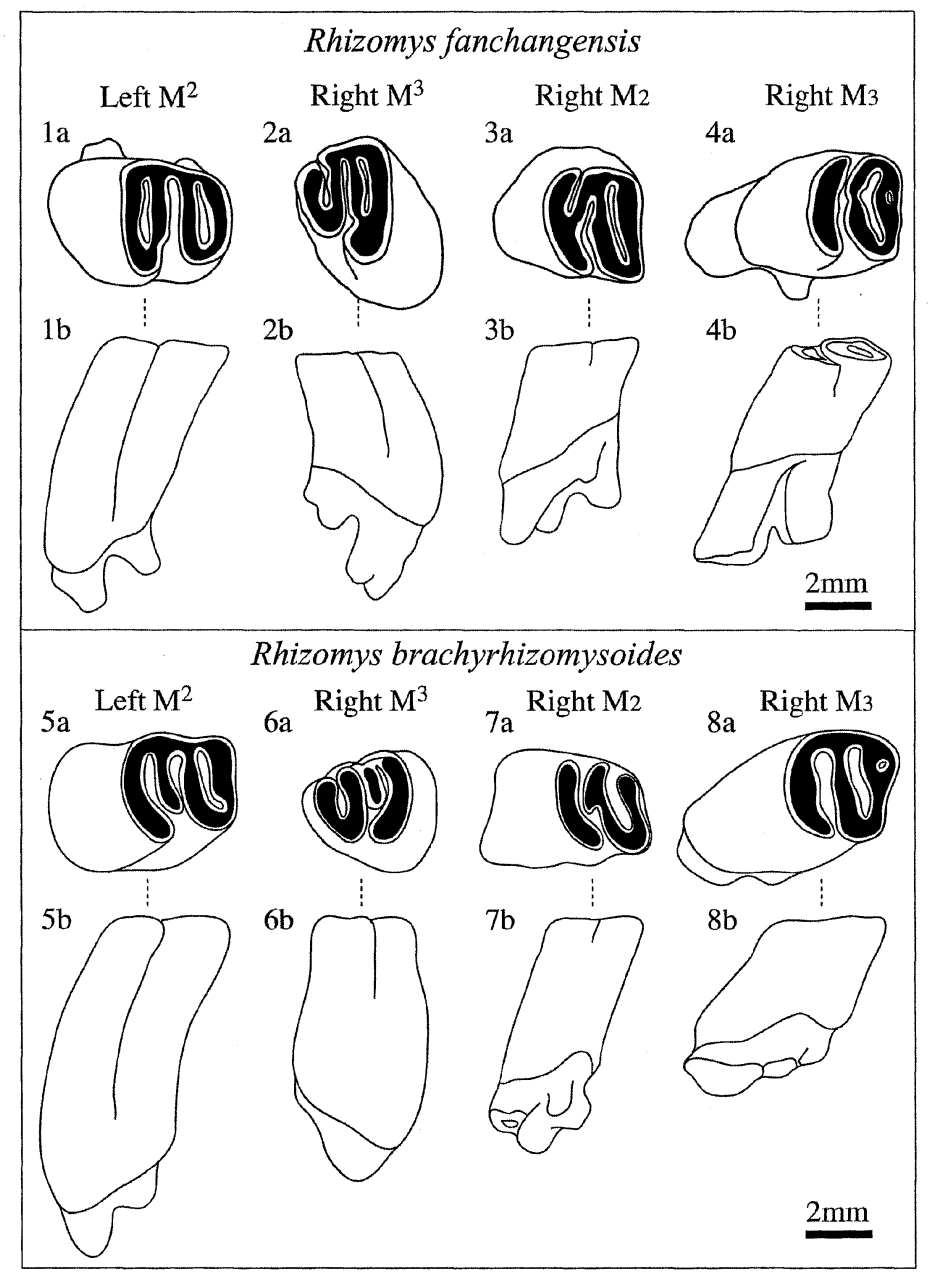

Fig. 8 Comparison of the molars of Rhizomys fanchangensis, sp. nov. and R. brachyrhizomysoides The differences in their hypsodonty, the groove on the lingual face of $\mathrm{M}^{2}$ and $\mathrm{M}^{3}$, and the buccal reentrant on the buccal face of $\mathrm{M}_{2}$ and $\mathrm{M}_{3}$ are shown. The figures of $R$. brachyrhizomysoides are redrawn from Figs. 52 and 53 of Zheng (1993). 1a, 1b. V13894.060, 2a, 2b. V13894.151, 3a, 3b. V13894.246, 4a, 4b. V13894.298, 1a, 2a, 3a, 4a, $5 \mathrm{a}, 6 \mathrm{a}, 7 \mathrm{a}, 8 \mathrm{a}$. occlusal view, 1b, 2b, 5b, 6b. lingual view, 3b, 4b, 7b, 8b. buccal view 
of $R$. brachyrhizomysoides were as brachydont as those of ancestral Brachyrhizomys shansius on the basis of his measurement of the vertical distance from the lower end of the lingual reentrant to the neck in $\mathrm{M}_{3}$. Our observasion, however, indicates that $B$. shansius is obviously lower-crowned than the present specimens, and thus $B$. shansius is further lower-crowned than R. brachyrhizomysoides (Figs. 7 and 8). This inconsistency with Zheng (1993) possibly results from obscurity of his measuring method of the vertical distance mentioned above, which does not always indicate hypsodonty of molars accurately. As regards the number of root, $\mathrm{M}^{2}, \mathrm{M}^{3}$ and $\mathrm{M}_{1}$ have three, two and two roots respectively in $R$. brachyrhizomysoides, but four, three and three in the present specimens.

$R$. troglodytes was first described as an extinct species from the Middle Pleistocene of Yenchingkou in Chongqing City (Matthew and Granger, 1923). On the basis of the detailed observation and statistical analysis of numerous remains from the same locality, Colbert and Hooijer (1953) concluded that it was a subspecies of an extant species, $R$. sinensis. They also provided the differential characters of troglodytes from extant forms that troglodytes has a relatively narrow skull and smaller teeth in relation to its skull size. On the other hand, Zheng (1993) distinguished troglodytes from sinensis in species level mainly by its smaller size and more brachydont molars. But, we agree with Colbert and Hooijer (1953) in referring it to $R$. sinensis troglodytes, because there are considerable overlaps in variation of size, skull characters and hypsodonty of molars between troglodytes and the extant $R$. sinensis. At any rate, the present specimens are easily distinguishable from troglodytes in having much smaller size, more brachydont molars, and different number of root in $\mathrm{M}^{2}$ and $\mathrm{M}_{2}$ (in troglodytes these molars have three roots each instead of four). These characters also distinguish the present specimens from $R$. sinensis.

As regards the two remaining extant species, $R$. sumatrensis and R. pruinosus, Allen (1940), Walker et al. (1975), Hu and Wang (1984), Corbet and Hill (1992), Huang et al. (1995) and Wang and $\mathrm{Hu}$ (1999) provide brief descriptions and figures of their skulls, mandibles and molars.
In the descriptions and figures, we cannot find out any significant differences between these two species and the present specimens, but the formers are significantly larger than the latters. Such a size difference is clear enough to distinguish $R$. sumatrensis and $R$. pruinosus from the present specimens.

Additionally, Young and Liu (1950) described three new extinct rhizomyid species from the Middle Pleistocene of Koloshan in Chongqing City. They were named Brachyrhizomys ultima, Rhizomys provestitus and $R$. szechuanensis. Recently Zheng (1993) reviewed them, and referred all of them to $R$. sinensis, because the mutual differences were resulted from only intraspecific variation.

In conclusion, the specimens described here are distinct from all the known species of Rhizomys listed above. Thus, we propose a new species, $R$. fanchangensis, for the specimens.

$R$. fanchangensis is chronologically the oldest species of Rhizomys so far known. It has such primitive characters as the size being small and the molars being less hypsodont. It has been generally believed that Brachyrhizomys is a probable ancestor of Rhizomys. The youngest species of Brachyrhizomys is the above-mentioned B. shansius from the Yushe Group in Shanxi Province, whose age ranges from 5.7 to $3.0 \mathrm{Ma}$ (Flynn, 1993). R. fanchangensis is, therefore, important for elucidating the transition from Brachyrhizomys to Rhizomys.

\section{Conclusion}

The fossil specimens described here were obtained from the Early Pleistocene of Renzidong Cave, central China. They show morphological characters of the subfamily Rhizomyinae within the family Rhizomyidae, but differ from the other subfamily, Tachyoryctinae. Within Rhizomyinae, they are assignable to the genus Rhizomys, but distinct from the remaining genera of the subfamily, Brachyrhizomys, Anepsirhizomys and Cannomys. The comparisons with the species of Rhizomys indicate that the specimens are different from all the known species ( $R$. schlosseri, R. brachyrhizomysoides, $R$. troglodytes, $R$. sinensis, $R$. sumatrensis and $R$. pruinosus). Thus, they are referred to a new 
extinct species of the Early Pleistocene which is named $R$. fanchangensis. This new species bridges the morphological and chronological gap between the Pliocene species of the ancestral genus, Brachyrhizomys, and Rhizomys species known from the later stages of the Quaternary.

\section{Acknowledgments}

We thank all the members of the Anhui Team of the research project "The early hominid evolution and environmental background in East Asia" for their great support in collecting the specimens described here. We are also indebted to Prof. T. Ozawa of Nagoya University for his support and encouragement, and to Mr. H. Taruno of Osaka Museum of Natural History for his valuable suggestions and giving us many facilities of our research in his museum. Thanks are due to Mr. I. Risho of Osaka City University for his assistance in preparing the draft of this paper.

This study has been financially supported by China National Key-Important Basic Research Project (grant no. PD. 98001) and by Grant-inAids for Scientific Research from the Japan Society of Promotion of Science (project nos. 13854001 and 14390027).

\section{References}

Allen, G.M. (1940) The mammals of China and Mongolia. Natural history of Central Asia, Vol. XI, Pt. 2. v-xxvi+621-1350, American Museum of Natural History.

Colbert, E.H. and Hooijer, D.A. (1953) Pleistocene mammals from the limestone fissures of Szechwan, China. Bull. Amer. Mus. Nat. Hist., 102, 1-134, pls. 140.

Corbet, G.B. and Hill, J.E. (1992) The mammals of the Indomalayan Region: A systematic review. 488 p, Oxford Univ. Press.

Flynn, L.J. (1982) Systematic revision of Siwalik Rhizomyidae (Rodentia). Geobios, 15, 327-389.

Flynn, L.J. (1993) A new bamboo rat from the Late Miocene of Yushe Basin. Vertebrata PalAsiatica,
31, 95-101. $(\mathrm{E}+\mathrm{C})$

Hu, J.Z. and Wang, Y.Z. (ed.) (1984) Sichuan fauna economica. Vol. 2 Mammals. 365 p, Sichuan Scientific and Technological Publishing House. (C)

Huang, W.J., Chen, Y.X. and Wen, Y.X. (1995) Chinese rodents. 308 p, Fudan Univ. Press. (C)

Jacobs, L.L. (1978) Fossil rodents (Rhizomyidae and Muridae) from Neogene Siwalik deposits, Pakistan. 103 p, Museum of Northern Arizona Press.

Jin, C.Z. and Zheng, L.T. (1998) Early Early Pleistocene evidence of human occupation from Fanchang, Anhui Province. Quaternary Sciences, 1998, 368. (C)

Jin, C.Z., Dong, W., Liu, J.Y., Wei, G.B., Xu, Q.Q., Zheng, J.J., Zheng, L.T., Han, L.G. and Wang, F.Z. (2000) A preliminary study on the Early Pleistocene deposits and the mammalian fauna from the Renzi Cave, Fanchang, Anhui, China. Acta Anthrop. Sinica, Supplement to vol. 19, 235-245.

Matthew, W.D. and Granger, W. (1923) New fossil mammals from the Pliocene of Sze-Chuan, China. Bull. Amer. Mus. Nat. Hist., 48, 563-598.

Teilhard de Chardin, P. (1942) New rodents of the Pliocene and Lower Pleistocene of North China. 101 p, Institut de Géo-Biologie, Pékin.

Teilhard de Chardin, P. and Young, C.C. (1931) Fossil mammals from the Late Cenozoic of northern China. Palaeont. Sinica, Ser. C, 9, fasc. 1, 1-67, pls. 110.

Walker, E.P., Warnick, F., Hamlet, S.E., Lange, K.I., Davis, M.A., Uible, H.E. and Wright, P.F. (1975) Mammals of the world (3rd ed.). 1,500 p, Johns Hopkins Univ. Press.

Wang, Y.Z. and Hu, J.C. (ed.) (1999) Imitatively-colored pictorial handbook of the mammals of Sichuan. 278 p, China Forestry Publishing House. (C)

Ye, X.K., Fang, Q.R., Hou, L.H., Zheng, S.H., Zhang, L. M., Gu, Y.M., Huang, W.B., Zhong, Z.K., Yang, X.L., Li, X.M., Cao, Y.S., Ji, H.X. and Yang, D.H. (1991) Vertebrate fossils. Wushan hominid site, 24-149, pls. 7-18+21-24, China Ocean Press. $(\mathrm{C}+\mathrm{E})$

Young, C.C. (1927) Fossile Nagetiere aus Nord-China. Palaeont. Sinica, Ser. C, 5, fasc. 3, 1-82, pls. 1-3.

Young, C.C. and Liu, P.T. (1950) On the mammalian fauna at Koloshan near Chungking, Szechuan. Bull. Geol. Soc. China, 30, 43-90.

Zheng, S.H. (1993) Quaternary rodents of SichuanGuizhou Area, China. 270 p, Science Press. $(C+E)$

(C) in Chinese, $(\mathrm{E}+\mathrm{C})$ in English with Chinese translation, $(\mathrm{C}+\mathrm{E})$ in Chinese with English abstract 


\title{
中国安徽省繁昌県人字洞産の前期更新世のタケネズミの新種
}

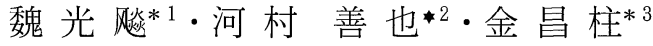

\begin{abstract}
〔要旨〕
中国安徽省にある人字洞の前期更新世の堆積物から産 出した多数のタケネズミ化石を系統・分類学的に記載し た。形態の特徵から，これらの化石はRhizomys 属の新 種で, R. fanchangensis と命名された. Rhizomys は現 生属であるが, この新種は絶滅種と考えられ, 小型で低 歯冠の曰歯をむつという原始的な特徵が見られる。この 新種は, Rhizomys 属の祖先と考えられる Brachyrhizomys

属の種のうち鮮新世の種と，これまでに知られている第 四紀の Rhizomys 属の種との中間の時代の屯ので, 形態 的にあ中間的な特徽が見られるため，それらの関係を明 らかにする上で重要である，なお，本論文では，鮮新世 と更新世の境界を，中国で一般に用いられているよう に，松山クロンとガウスクロンの境界 $(2.58 \mathrm{Ma})$ と考え ている.
\end{abstract}

*1 中国科学院古春椎動物古人類研究所 北京市西直門外大街 142 号 (現住所: 大阪市立大学大学院理学研究科地球学教室 二558-8585 大阪市住吉区杉本 3-3-138.)

*2（コレスポンディング・オーサー）愛知教育大学理科教育講座地学領域 邓448-8542 愛知県刈谷市井ヶ谷町広沢 1.

$* 3$ 中国科学院古脊椎動物古人類研究所 北京市西直門外大街 142 号. 